\title{
A Financial Management Application Approach towards "Industry 4.0 Revolutionary Era" in Islamic Boarding High School of Insan Cendekia Gorontalo
}

\author{
Sitti Roskina Mas \\ Department of Educational Administration \\ Universitas Negeri Gorontalo, Indonesia \\ sittiroskina@ung.ac.id
}

\author{
Muhammad A. Sahada \\ Department of Educational Administration \\ Universitas Negeri Gorontalo, Indonesia \\ sahadaam@gmail.com
}

\author{
Arwildayanto \\ Department of Educational Administration \\ Universitas Negeri Gorontalo, Indonesia \\ arwildayanto@ung.ac.id
}

\begin{abstract}
This research aimed to describe (1) the system flow of the financial management applications in Islamic Boarding High School of Insan Cendekia Gorontalo, (2) the benefits of using the applications for the school, and (3) the implications of using the applications. The approach used in this research was a qualitative approach with case study design. The data collection techniques used were interview, observation and documentation. The research results showed that (1) the system flow of the financial management applications consisted of 3 applications namely SAS, SAIBA, and SIMAK BMN which in general, the process of the 3 applications were almost same where the operator firstly entered the financial data as input to obtain the output in the form of financial reports. (2) the benefits of using these applications were the cost of preparing the financial reports could be reduced; by using this application, the integration process that had been carried out in stages now does not need to be done anymore, (3) using the applications in the school gave a very significant impact on the school financial management, such as ensuring transparency and accountability in terms of using the school budget. Therefore, it is recommended (1) to Islamic Boarding High School of Insan Cendekia Gorontalo to be pleased to provide technical guidance to schools that have not yet implemented the application-based financial management system so that in the future, all manual-based financial reporting activities are transferred to digital applications, and (2) for financial staff to always update financial applications to maximize the financial reporting.
\end{abstract}

Keywords: financial management, SA application, SAIBA application, SIMAK BMN application

\section{INTRODUCTION}

Information-technology-based

financial

management is a breakthrough made by the government in facilitating financial management in an agency as stated by Secretary of the Ministry of Education and Culture, Wowon Widaryat, that the Government has implemented various efforts to carry out reforms in the field of state financial management as mandated by Law Number 17 of 2003 concerning State Finance (UU17/2003) and Law Number 1 of 2004 concerning State Treasury [16]. Information-technology-based financial management is expected to have an economical, effective and efficient impact on the general financial management system by manual methods (manual method).

Horak states the next key component of the phenomenon of the Industry 4.0 is the Internet of Things that are smart factories which will collect big data [4]. This data will be analyzed through computer technology, and the company obtains the best information about the needs, behavior, and requirements of its customers, while the company will have information about the behavior of produced production, and they will receive products according to their wishes. In educational sectors, the Industry 4.0 are very essential for having the excellent services to students and academic staff. Financial management in education is very important aspect for implementing process of education, financial management that consists of planning, processing, monitoring and evaluation of program and budget system.

End-to-end transparency is provided over the manufacturing process, facilitating optimized decisionmaking. Industry 4.0 will also result in new way of creating values and new business model in the economy [3]. The new business model is based on the virtual copies of process of the suppliers. These processes will be interconnected with virtual copies of the process in the production company.

\section{METHOD}

The approach used by the author in this study is a qualitative approach with case study research design. Data collection is done through techniques: (1) interviews, (2) observations and (3) documentation. Data analysis techniques are carried out through steps: (1) data reduction, (2) data presentation and (3) conclusion 
drawing / verification. The data immunity test uses: credibility and confirmability. Data credibility is done through triangulation techniques and sources, while confirmability is done through an audit behind the data to informants to determine the accuracy of the data.

\section{FINDING AND DISCUSSION}

The results of the research on the use of financial applications SAS, SAIBA, SIMAK, and BMN in Islamic Boarding School of Insan Cendekia Gorontalo provide benefits including: (1) efficiency and effectiveness in financial management in schools, (2). has a very significant impact on financial management in schools because it can guarantee financial transparency and accountability so that it can realize a quality, and auditable financial management system, and be accountable for the use of the budget. The results of the study are described as follows:

System flow of financial management application in Insan Cendekia Islamic Boarding High School

The process of reporting financial information can be done quickly through the SAS financial manager application system, SIMAK BMN and SAIBA. These applications are used by interested parties in schools to facilitate financial reporting information as explained by Bodnar and Hopwood (2004) that "accounting information system is a collection of resources, such as humans and equipment designed to convert financial data and other data into information communicated to various decision makers. "

SAS application system is an application that is used to create Request Payment Letter (RPL), Warrant Payment Letter (WPL), and Treasurer Agency Report System (SILABI) and also several other integrated functions in the context of implementing the State Budget. There are several modules in the application for data backup, ceiling transfer and revision, reference settings, making RPL and WPL, recording the Fund Disbursement Warrants number and making treasurer accountability reports.

While the SAIBA financial manager application system is intended for recording DIPA, namely recording transactions in the allocation of the Shopping and Income Ceiling in DIPA. Recording of these transactions is carried out through cash journals and will be posted into the recording of operational expenditure transactions based on the existence of sources of expenditure documents.

Thus, the education management application system can improve and support the Islamic Boarding High School of Insan Cendekia Gorontalo in the reporting process of the use of the budget used to support the educational process that runs in the school and will make the school more trusted in the process of managing state finances.

Benefits of financial management application to Insan Cendekia Islamic Boarding High School

Islamic Boarding High School of Insan Cendekia Gorontalo, in the process of financial management, uses accounting information technology provided by the government, in this case the finance ministry, according to the accrual-based time frame of implementation of Government Accounting Standards. As stipulated in Government Regulation 71/2010, then 2014 was the last year the government was allowed to use the cash-based towards the accrual-based. Accrual-based accounting is an accounting-based in which economic transactions and other events are recognized, recorded and presented in the financial statements at the time of the transaction, regardless of the time cash or cash equivalents are received or paid.

With the application of an application-based financial management system, financial staff in this school are greatly assisted in making budget accountability reports, because using these applications make it easier to make financial reports rather than manual processes, which are more time-consuming. The principal of Islamic Boarding High School of Insan Cendekia greatly appreciates the application of financial management application programs, because with these applications, the process of financial transactions carried out by the school can be easily reported, where all processes for the use of state budgets that are intended for funding in the school can be monitored by interested parties such as Supreme Audit Agency. Thus, the school can guarantee transparency and accountability in budget use.

Implication of using financial management application in Insan Cendekia Islamic Boarding High School

The use of financial management applications in Islamic Boarding High School of Insan Cendekia Gorontalo makes various jobs related to financial management that manually takes a long time and requires a lot of energy no longer occurs and this application increases the efficiency of accounting and financial management in the school. The financial management system functions to automate various jobs carried out by the school finance staff and facilitate financial staff in making financial reports and storing transaction data. Thus, the school finance staff can focus more on other important jobs and have an impact on the efficiency and effectiveness of financial staff performance.

Suoth et al stated that effectiveness is the relationship between output and purpose. The greater the contribution of output to achieving goals, the more effective the organization, program, or activity. If efficiency focuses on outputs and processes, effectiveness focuses on outcomes [12]. An organization, program, or activity is considered effective if the output produced can meet the expected goals or spending wisely.

Some of the effects of the use of financial management applications felt at Islamic Boarding High School of Insan Cendekia Gorontalo, which can accelerate the process of integration of financial statements, because there are financial applications, the process of integrating financial statements in stages from the work unit level to the ministry / institution is no longer needed. Financial applications will also reduce the cost of preparing reports by reducing paper use in the preparation of reports (paperless). The ministry / financial institution does not need to request a hardcopy report 
from the results of reports inputted by the school because they can print reports from the same source. Therefore, the application system has a good impact on the administration of financial statements in school.ehavior of principal and teachers become role models to students in school.

\section{CONCLUSION}

Based on the research results it can be concluded that (1) the system flow of the financial management applications consisted of 3 applications namely SAS, SAIBA, and SIMAK BMN which in general, the process of the 3 applications were almost same where the operator firstly entered the financial data as input to obtain the output in the form of financial reports. (2) the benefits of using these applications were the cost of preparing the financial reports could be reduced; by using this application, the integration process that had been carried out in stages now does not need to be done anymore, (3) using the applications in the school gave a very significant impact on the school financial management, such as ensuring transparency and accountability in terms of using the school budget, it is more efficient and can ensure the financial data security.

\section{REFERENCES}

[1] A Arwildayanto., Nina L., \& Warni T. S. Manajemen Keuangan dan Pembiayaan Pendidikan. Bandung : Widya Padjadjaran Anggota IKAPI JABAR. 2017.

[2] Bafadal, Ibrahim. Manajemen Perlengkapan Sekolah, Teori, dan Aplikasinya. Jakarta..PT. Bumi Aksara. 2004.

[3] Havle, O. Prumysl $4.0 \mathrm{z}$ pohledu MSP. In PPP 4.0Pripraveno proPrymysl 4.0 Brono, 16-22. 2016.

[4] Horak, Josef. Does Industry 4.0 Influence Efficiency of Financial Management of a Company? Pargue: The 10th International Days of Statistics and Economics. 2016.

[5] Jin Chi, Jin Ligo, Jingjing Yang. Institutional Stock Ownership and Firm Innovation: Evidence from China Journal of Multinational Financial Management, Volume 50 June 2019 pp 44-57. 2019

[6] John, Wachowics. Prinsip-prinsip Manajemen Keuangan. Edisi kedua belas. Jakarta : Salemba Empat. 2005.

[7] Keith. Eduacation, Management and Participation; New Direction in Eduacational Administration. Boston: Allyn \& Bacon. 1991.
[8] Mestry, Raj dan Tom Bisschoff. Financial School Management Explained. Cape Town: Pearson Education South Afria. 2009.

[9] Mishra, Sweta, Mukherjee, Tutun. Corporate Governance and Efficacy in Working Capital Management: A Study. Account and Financial management Journal Volume 3 Issue 09 September 2019 (PP No. 1732-1738). 2018

[10] Peraturan Pemerintah Republik Indonesia Nomor 48 Tahun 2008 tentang Pendanaan Pendidikan

[11] Peraturan Pemerintah Republik Indonesia Nomor 48 Tahun 2008 tentang Pendanaan Pendidikan

[12] Suoth, Novelya dkk. Pengukuran Efisiensi Dan Efektivitas Pengelolaan Keuangan Daerah Pada Dinas Pengelola Keuangan, Pendapatan Dan Aset (Dpkpa) Kabupaten Minahasa Selatan Universitas Sam Ratulangi, Manado. 2016.

[13] Sutomo. Manajemen Sekolah. Semarang: UPT Unnes Press. 2011.

[14] Undang-Undang Nomor 1 Tahun 2004 tentang Perbendaharaan Negara.

[15] Undang-undang Nomor 15 Tahun 2017 tentang Pemeriksaan dan Tanggung Jawab Keuangan Negara.

[16] Undang-Undang Nomor 17 tahun 2003 tentang Keuangan Negara (UU17/2003)

[17] Yulianti. Pengaruh Trust Dan Komitmen Kerja Terhadap Adopsi Simbolik Pengguna Pada Implementasi Sistem Aplikasi Satker (Studi Kasus Instansi Pemerintah di Wilayah Kabupaten Kulon Progo).Universitas Gajah Mada. 2016. 